\title{
The 'Separate Performative' Account OF THE GERMAN RIGHT DISLOCATION*
}

\author{
Maria Averintseva-Klisch, \\ HU Berlin \\ maria.averintseva@rz.hu-berlin.de
}

\begin{abstract}
In my paper, I show that the so-called German right dislocation actually comprises two distinct constructions, which I label 'right dislocation proper' and 'afterthought'. These differ in their prosodic and syntactic properties, as well as in their discourse functions. The paper is primarily concerned with the right dislocation proper (RD). I present a semantic analysis of RD based on the 'separate performative' account of Potts $(2004,2005)$ and Portner (forthc.). This analysis allows a description of the semantic contribution of RD to its host sentence, as well as explaining certain semantic constraints on the kind of NP in the RD construction.
\end{abstract}

\section{Introduction}

In this paper I discuss the construction that is traditionally called 'German right dislocation' (cf. Altmann (1981)). This is a structure consisting of an NP at the end of the clause and a coreferent proform inside the clause, as in (1):

a. Ich mag sie ${ }_{\mathrm{i}}$ nicht, (ich meine) die Serena ${ }_{i}$ I like her not (I mean) the Serena ${ }_{i}$.

b. Und dann passierte das Unglück, (ich meine) dieser schreckliche Autounfall. And then happened the misfortune ${ }_{i}$ (I mean) this terrible traffic-accident $_{i}$.

Traditional analyses of German right dislocation (Altmann (1981), Auer (1991), Selting (1994), Uhmann (1993, 1997), Zifonun et al. (1997)) assume that right dislocation is a strategy of spoken German, which enables the speaker to resolve a (pro)nominal reference that might be unclear to the hearer. This analysis accounts for (1), but is problematic for (2), where pronominal reference is undoubtedly clear:

a. "Ein Taifun!" rief Lukas dem Kapitän zu. "Da ist er!" Ja, da "A typhoon!" called Lukas the captain to. "Here is he!" Yes there war er, der Taifun.

was $_{i}$ the typhoon MASK $_{\text {. }}$.

[M. Ende, Jim Knopf und die Wilde 13: 190]

b. [...] wenn ihnen das Glück nicht den Karpfen Cyprinus zur Hilfe geschickt [...] if them the fortune not the carp Cyprinus for help sent hätte! Ahnungslos kam er dahergeschwommen, der Karpfen Cyprinus. had! suspecting-not came he $e_{i}$ swimming-along the carp $_{\mathrm{MASK}}$ Cyprinus $_{i}$.

[O. Preussler, Der kleine Wassermann: 28]

\footnotetext{
* The research for this paper has been conducted as part of my Ph.D. project, which is financed by the DFG within the graduate school "Ecomony and Complexity in Language" (HU Berlin / Potsdam Univ.). I wish to thank my supervisor Claudia Maienborn for her constant support, Manfred Consten, Mareile Knees and Barbara Schlücker for helpful comments on this paper, as well as the audience of Sinn und Bedeutung 10 for stimulating feedback.
} 
In (2), the function of the right dislocation is not to disambiguate a pronominal reference, as it is not ambiguous at all, but to mark the referent of the right-peripheral NP as being especially important for the succeeding discourse. In other words, the typhoon (2a) and, respectively, the carp (2b) are set as what the following discourse segment is about. In fact, in (2a) the following segment offers a detailed description of the typhoon, and ( $2 b)$ continues describing the carp, its appearance and habits ${ }^{1}$.

It has already been noticed in the literature that right dislocation might have an additional function of "attracting the attention of the addressee" to the right-peripheral NP (Zifonun et al. (1997:548), transl. mine: MA). I argue that disambiguation of a pronominal reference and marking the importance of the discourse referent are not two functions of one construction, but that there are in fact two constructions subsumed under the label of German right dislocation: right dislocation proper (further right dislocation, RD) and afterthought (AT). In the following I will show that RD and AT differ not only with respect to their discourse functions, but also in their prosodic and syntactic features.

The paper is organized as follows: in section 2 the prosodic, syntactic and discoursefunctional properties of RD and AT are briefly introduced. I show that RD is prosodically and syntactically part of its host sentence, whereas AT is an 'orphan' that gets integrated into its host sentence only at the level of the discourse. Then I turn to the main subject of the paper, i.e. to the semantics of RD, or, more precisely, the semantic contribution of RD to its host sentence. In section 3 I introduce the 'separate performative account' (Potts (2004, 2005), Portner (forthc.)). I will show how Portner's account of English topics can be applied to the analysis of RD. Section 4 then discusses how the semantics of RD determines its discourse function of marking the discourse topic referent for the discourse segment following RD. Certain peculiarities of RD concerning the semantic status of the RD-NP are dwelt upon in this context. Finally, in section 5 the results are summed up and some conclusions are drawn.

\section{RD vs. AT: prosodic, syntactic and discourse-functional differences}

In order to concentrate on the semantics of RD I first have to clearly distinguish between RD and AT. Therefore, in this section I will introduce the prosodic and syntactic differences between RD and AT. They all suggest that RD is prosodically and syntactically part of its host sentence, while AT is not. Many of these differences have been already pointed out in Altmann (1981). However, as Altmann does not make any differentiations within right dislocation constructions, his approach is to state a certain prosodic and syntactic pattern for German right dislocation, whereupon he has to allow for numerous exceptions from this pattern. Distinguishing between RD and AT allows us to dispense with most exceptions, and to describe distinct patterns for RD and AT instead. In section 2.2. I will then specify the discourse functions of RD and AT which have been mentioned above.

\subsection{RD vs. AT: prosodic and syntactic differences}

RD is prosodically integrated into its host sentence (3a), i.e. it continues the tone movement of the host sentence and thus does not build a prosodic unit of its own, whereas AT builds a prosodic unit (optionally divided by a pause from the clause) with a tone movement and a clause-like accent of its own, (3b): ${ }^{2}$

\footnotetext{
${ }^{1}$ Moreover, (2) shows that right dislocation is used also in written, and not only in spoken, discourse.

${ }^{2}$ Altmann (1981) observes two distinct prosodic patterns by what he calls "German right dislocation", but does not explain this observation. Selting (1994) differentiates two kinds of "right dislocation" on the basis of their
} 
(3)
a. [Ich MAG sie nicht, die Brigitte $_{\mathrm{i}}$ ].
b. [Ich MAG sie nicht], |[die BriGITte ${ }_{\mathrm{i}}$ ].
I like her not the Brigitte.
(|: pause; [ ]: prosodic unit; CAPITALS: main accent)

Prosodic differences go along with syntactic differences: RD is also syntactically part of its host sentence, whereas AT is an independent unit. The syntactic differences are listed below ${ }^{3}$.

- Strict morphological agreement (in case, gender and number) between the clauseinternal pro-form and the NP is obligatory for RD and optional for AT, cf. (4) vs. (5):
("Der Taifun!"
rief Lukas dem Kapitän zu. "Da
ist er!") Ja, da war
("The typhoon $n_{\mathrm{MASK}}$ !" called Lukas the captain to. "Here is he!") Yes, there was

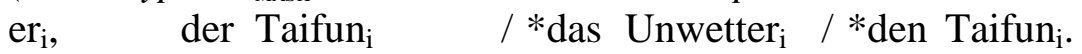
RD
$h e_{\text {NOM_MASK }}$ the typhoon $n_{\text {NOM_MASK }} / *$ the storm $_{\text {NOM_MASK }} / *$ the typhoon ACC_MASK $_{\text {A }}$
a. Der Zwiespalt [...] zerriss
$\mathrm{ihn}_{\mathrm{i}}$
fast: [Fürst
Georg III., der Reformator

The dichotomy [...] tore-apart

him $_{\mathrm{ACC}}$ nearly: prince Georg III [the reformer

von Anhalt-Dessau $]_{i}$.

of Anhalt-Dessau] $]_{\text {Noм. }}$.

[Chrismon 05/2004]

b. Und dann passierte das Unglück, (ich meine) dieser schreckliche And then happened the misfortune NEUTR $_{\text {(I mean) [this terrible }}$ Autounfall. traffic-accident $]_{\text {MASK }}$.

- A subordinate clause between the clause-internal pro-form and the NP is impossible for RD and possible for AT, cf. (6):

a. „Der Taifun“, rief Lukas dem Kapitän zu. „Da ist er!“ Ja, da war "The typhoon!" calledLukas the captain to. "Here is he!" Yes, here was er, *den sie alle gefürchtet haben, der Taifun. $h e_{i} *$ whom they all afraid-of were the typhoon . $^{\text {. }}$

b. So ereilte den TV-Western das, wovor sich der Filmwestern durch So overtook the $T V$-western ACC $_{\text {this }}$ what-of refl the cinema-western through einen stilvollen Selbstmord entzog, der schleichende Tod. AT a classy suicide escaped [the sneaky death] ${ }_{i}$.

[Konkret-Korpus: 289311]

- Optional additions (ich meine ('I mean'), also ('that is'), tatsächlich ('really') etc.) between the clause-internal pro-form and the NP are possible for AT but not for RD, ${ }^{4} \mathrm{cf} .(7)$ :

prosodic difference. In her account, however, prosodic difference is the only important one; functionally, both kinds of "right dislocation" are analysed as a repair strategy. As I show above, RD and AT do not only differ with regard to prosody, but also syntactically as well as in their discourse functions. In a similar way, Fretheim (1995) shows that in Norwegian prosody also helps to distinguish between RD and AT; as in German, prosodically integrated structures are RDs, and prosodically non-integrated ones ATs.

${ }^{3}$ Here I only give a brief listing of syntactic differences, since they are not the main subject of this paper. See Averintseva-Klisch (forthc. a \& b) for more details.

${ }^{4}$ As the examples show, the (im)possibility of additions with RD and AT is not due to the meaning and function of the addition, as one might be tempted to believe in the case of ich meine / also ('I mean' / 'that is'), which are additions explicitly assisting the reference clarifying function of AT. Also additions like natürlich ('of course'), tatsächlich ('really') etc., which are insensitive to the functional difference between RD and AT, are bad with RD and perfectly acceptable with AT. Thus, this difference seems to be a syntactic one. 
a. „Der Taifun“, rief Lukas dem Kapitän zu. „Da ist er!“ Ja, da war "The typhoon!" called Lukas the captain to. "Here is he!" Yes, here was er, (*ich meine / *also / *tatsächlich) der Taifun. he $(* I \quad$ mean /*that-is/*really) the typhoon.

b. (Lisa und Melanie haben sich gestritten.)

(Lisa and Melanie quarrelled.)

Dann ist sie weggelaufen, | (ich meine / also) Lisa.

Then is she run-away (I mean / that-is) Lisa.

- The NP is not bound at the right-peripheral position in the case of AT, but can have a fairly free position in its host sentence, while RD is only possible at the right periphery, cf. (8) vs. (9):

a. Ich habe ihn gestern nur mit Mühe wiedererkannt, | ich meine den PEter. I have him yesterday onlywith effort recognized I mean the Peter.

b. Ich habe ihn, | ich meine den PEter |, gestern nur mit Mühe wiedererkannt. I have him I mean the Peter yesterday onlywith effort recognized.

c. Ich habe ihn gestern, | ich meine den PEter,|nur mit Mühe wiedererkannt. I have him yesterday I mean the Peter only with effort recognized.

I hardly recognized him yesterday, I mean Peter.

(9) a. (Dieser Peter!) Ich kann ihn ${ }_{i}$ nicht leiden, den Peter ${ }_{i}$. (This Peter!) I can him not suffer the Peter

b. (Dieser Peter!) *Ich kann ihn ${ }_{i}$, den Peter ${ }_{i}$, nicht leiden ${ }^{5}$. (This Peter!) I can him the Peter not suffer

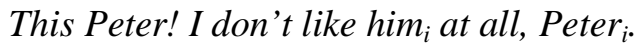

To summarize: there is ample evidence that RD belongs prosodically and syntactically to its host sentence in a much more straightforward way than AT. Prosodically, RD is a part of its host sentence's tone contour. Morphological agreement of the RD-NP with the clause-internal pro-form suggests that NP is part of the clause, as morphological agreement is a sentencebound phenomenon. Moreover, RD occupies a fixed position in the host sentence at its right periphery, and does not allow subordinate clause insertion nor optional additions of any kind between the host sentence and the RD-NP. This leads to the assumption that RD is part of its host sentence, presumably the right adjunct to the IP. An ultimate syntactic analysis of RD would exceed the limits of this paper.

AT, on the contrary, can vary its position in its host sentence. Furthermore, AT does not strictly require morphological agreement between the NP and the clause-internal pronoun, and it allows various insertions between the host sentence and AT-NP. All in all, AT appears to be syntactically fairly free. In this paper I consider AT only as far as it is necessary for delimiting $\mathrm{RD}$ as a separate construction. More details about AT are given in Averintseva-Klisch (forthc. a \& b). I propose to analyze AT as an 'orphan' in terms of Haegeman (1991). An orphan is a unit that is syntactically independent of its host sentence, but gets integrated into it only at the level of the discourse via some discourse relation.

The topic of this paper is the semantics of RD and how it determines the function RD has in the discourse. I first point to the discourse-functional differences between RD and AT. Then I concentrate on RD and its semantics.

\footnotetext{
${ }^{5}$ Here I use the prosodic structure as a diagnostics to distinguish between RD and AT. This means that for cases marked as RD I assume prosodic integration. In other words, (9b) is bad with the RD prosody. It would, however, be perfectly well-formed as an AT construction if the NP builds a prosodic unit of its own.
} 


\subsection{RD vs. AT: discourse-functional differences}

As shown above, RD marks a discourse referent as being the 'theme' for the following discourse segment. ${ }^{6}$ In the following, I name the discourse referent about which a certain discourse segment is 'discourse topic referent'. ${ }^{7}$ RD thus marks a discourse referent ${ }^{8}$ as the discourse topic referent for the segment following the RD, cf. (10):

(10) (Und als der König seine Frau verloren hatte, bedauerte ihn die Dutitre: "Ach ja, für Ihnen is et ooch nich so leicht [...].")

(And when the king lost his wife, Dutitre pitied him: "Dear me, I should say, for you things aren't that easy either [...]).

Sie war ein Original, die Madame Dutitre.

She $_{i}$ was an original the Madame Dutitre . $_{\text {. }}$

(She was somewhat special, that Madame Dutitre.)

(Sie verstand nie, warum man über ihre Aussprüche lachte. Sie war eben echt und lebte, wie alle wirklich originalen Menschen, aus dem Unbewussten. Kein falscher Ton kam deshalb bei ihr auf.)

(She never understood why everybody always laughed at her remarks. She was genuine and lived unconsciously, as all unique people do. She never came across as being artificial.)

[Fischer-Fabian, S. (1959): Berlin-Evergreen: 125]

In (10), RD marks that the following is about Madame Dutitre. Madame Dutitre is thus explicitly set as the discourse topic referent for the segment following the right dislocation. A reference clarification would not be plausible here, as Madame Dutitre is clearly available (and most salient) as the referent for the pronoun sie ('she').

As for AT, its discourse function is to clarify a potentially unclear reference, as in (11):

(11) (Sie [Die Mutter] hat den Wohnzimmerschrank aber auch nicht leiden können,[...], aber mein Vater hat sich auf keine billigen Sachen mehr eingelassen,)

(Mother hated the wardrobe ${ }_{\mathrm{MASC}},[. .$.$] , but my father didn't want to have any more cheap things$ around).

\footnotetext{
${ }^{6}$ I understand discourse segment intuitively as a relatively small span of a discourse (minimally one utterance) that is characterized through a fairly tight thematic contiguity. In written language a discourse segment mostly corresponds to a paragraph (cf. also Goutsos (1997)).

${ }^{7}$ I do not attempt a theoretical solution to the problem of the status of discourse topic, which has been extensively discussed in literature. See e.g. Brown \& Yule (1983/2004), Goutsos (1997) and, more recently, Büring (2003), Asher (2004a \& b), Kehler (2004), Oberlander (2004), Stede (2004) and Zeevat (2004), to name just a few, for the questions of what a discourse topic is (possible answers are: a proposition, a question the discourse answers, an entity etc.) and whether modeling of the discourse needs this concept in the first place. However, the existence of some kind of entity that is most salient at a given stage of the discourse and that is relevant for establishing coherence seems to be uncontroversial; it is for example the common point of the papers in the recent issue of Theoretical Linguistics dedicated to discourse topics. The autors use different terms for the same intuition of "the thing" that "cohesive chunks of text are about" (Asher (2004b: 255)): 'recurring sentence topic' in Oberlander (2004), 'local topics within discourse segments' in Kehler (2004), 'protagonist' in Zeevat (2004) and 'Discourse topic 1' in Stede (2004).

${ }^{8}$ There are certain conditions on the discourse referent here, e.g. it has to be discourse-old in the sense of Prince (1992); see Averintseva-Klisch (forthc. a).
} 


er ist $\mathrm{ihr}$
$\mathrm{He}_{i}$ is for-her f $_{j}$ also too dark been

Here the context suggests that the most plausible referent for the pronoun $\operatorname{er}$ ('he') is the father, and the reference to the wardrobe is explicitly resolved with the help of AT.

To sum up: there is ample prosodic, syntactic and discourse-functional evidence that RD and AT are two different constructions. RD is prosodically and syntactically part of its host sentence, presumably a right IP-adjunct. Its role in the discourse is to mark the discourse topic referent for the following segment. AT is an 'orphan', i.e. it is prosodically and syntactically free. It is used as an explicit clarification of an unclear or ambiguous reference.

In the following I am exclusively concerned with RD. Being a part of its host sentence it is expected to contribute to its semantics. I will investigate the semantic fundamentals of discourse topic referent marking and show how the contribution of the right dislocation to the semantics of the whole sentence arises.

\section{RD as separate performative}

In this section, I first introduce the theoretical framework I use, the 'separate performative account' developed by Potts $(2004,2005)$ and Portner (forthc.), thereafter adapting it to account for the meaning contribution of RD to its host sentence.

\section{1 'Separate performative account': Potts (2004, 2005), Portner (forthc.)}

Potts (2004, 2005) and Portner (forthc.) observe that different constructions such as for example vocatives, NP appositions or topic constructions introduce a special kind of meaning, which they call 'separate performative' or 'expressive content'. ${ }^{10}$ So, besides stating that Amir is from Israel, which is the regular, 'at-issue', meaning of the sentence in (12), a separate performative is introduced: "I assert that Amir is my new neighbour":

(12) Amir, my new neighbour, is from Israel.

at-issue meaning: $\quad$ Amir is from Israel (in a given world w)

separate performative: I thereby assert that Amir is my new neighbour (in w)

This additional content, introduced through the NP apposition, is a separate performative speech act, with which the speaker instructs the addressee as to how the at-issue-meaning has to be integrated in the discourse model. Being a performative, this 'expressive' meaning does not influence the truth conditions of the sentence as it is automatically true when understood. Expressive meaning is non-compositional in its character; this means, it does not contribute in a regular compositional way to the semantics of the sentence, nor is there a complex compositionality of expressive meaning. That is, a sentence might have several expressive meanings, which are then non-compositionally, in a purely additive way "gathered together" to the overall expressive meaning of the sentence. Therefore according to Potts $(2004,2005)$ and Portner (forthc.) expressive meaning constitutes a separate "dimension of meaning" (cf. Portner (2005: 2)). A final meaning of a given sentence $S$ is then a set of two meaning dimensions, cf. (13):

\footnotetext{
${ }^{9}$ I owe this example to Hélène Vinckel, p.c.

${ }^{10}$ A working definition of expressive content is: "Expressive content is non-displaceable, speaker-oriented meaning that is independent of the main semantic content of the sentence in question." [Potts (2003:8)]. Following Potts and Portner, I use the terms "expressive content" and "separate performative" synonymously in my paper.
} 
(13) for a sentence $S$ : final meaning $:\left\langle A_{S}, C_{S}\right\rangle$

$A_{S}$ : at-issue meaning of $S$

$\mathrm{C}_{\mathrm{S}}$ : set of expressive meanings of $\mathrm{S}\left(\mathrm{C}_{\mathrm{S}}:\left\langle\mathrm{C} 1_{\mathrm{S}}, \mathrm{C} 2_{\mathrm{S}} \ldots\right\rangle\right)$

Whereas $A_{S}$ is constituted compositionally, $C_{S}$ is a simple sum of expressive meanings.

Thus, expressive meaning percolates up the tree as a separate set of meanings, cf. (14) (see also Portner (2005: 9)):

(14) Amir, my new neighbour, is from Israel.

$\left[\left[\text { my new neighbour } \mathrm{appos}_{\mathrm{c}}\right]\right]_{\mathrm{c}}=\varnothing$

$\left[\left[\text { my new neighbour }{ }_{\text {appos }}\right]\right]_{\mathrm{c}}^{\mathrm{C}}=[\lambda \mathrm{x} \lambda \mathrm{w} . \mathrm{x}$ is my new neighbour in $\mathrm{w}]$

[[Amir my new neighbour $\left.\left.{ }_{\text {appos }}\right]\right]_{\mathrm{c}}=$ Amir

[[Amir my new neighbour $\left.\left.{ }_{\text {appos }}\right]\right]_{\mathrm{c}}^{\mathrm{C}}=\{[\lambda \mathrm{w}$. Amir is my new neighbour in $\mathrm{w}]\}$

$\left[\left[\text { Amir my new neighbour }{ }_{\text {appos }} \text { is from Israel }\right]\right]_{\mathrm{c}}=[\lambda \mathrm{w}$. Amir is from Israel in w $]$

$\left[\left[\text { Amir my new neighbour }{ }_{\text {appos }} \text { is from Israel }\right]\right]_{c}^{C}=\{[\lambda \mathrm{w}$. Amir is my new neighbour in $w]\}$

interpretation functions: [[ ] ] $]_{c}$ : regular content; [ [ ] $]_{c}^{\mathrm{C}}$ : expressive content

Semantic embedding constitutes strong evidence for separate performatives being a meaning dimension of their own. Potts (2004) argues that expressive meanings are semantically nonembeddable. So, in (15), the expressive meaning introduced by the apposition my new neighbour cannot be contributed to Felix, but only to the speaker of the matrix sentence (see also Potts $(2004,24))$ :

(14) As Felix said, Amir, my new neighbour, is from Israel.

a. $\quad=$ Felix said that Amir is from Israel.

b. $\quad \neq$ Felix said that Amir is my new neighbour.

c. $\quad \neq$ Felix said that Amir is my new neighbour and that he is from Israel.

Portner (forthc.) proposes an analysis of English left dislocation (E-LD; 'topic' in Portner's terminology), according to which its expressive meaning is "speaker's mental representation of $X$ is active (in a given world $w$ )", as in (16):

(16) Mary, I like her a lot.

at-issue meaning: $\quad[\lambda \mathrm{w}$. speaker likes Mary in $\mathrm{w}]$

expressive meaning: $\{[\lambda \mathrm{w}$. speaker's mental representation of Mary is active in $w]\}$

[cf. Portner (2005: 12)]

Portner (forthc.) argues against his own earlier proposal (Portner (2004)), that the expressive meaning of E-LD cannot be an addressee-oriented request "I thereby request that you activate your mental representation of $X$ " (Portner (2004: 9)). He shows that there are theoretical problems with this expressive meaning variant if one takes embedded topics (E-LDs) like (17) into account. These have two possible variants of expressive meaning, the regular one (1) and the embedded one (2):

(17) John said that, as for Maria, she is nice.

at-issue meaning: [ $\lambda \mathrm{w}$. John said that Maria is nice in $w$ ]

expressive meaning (informal): 1 . The speaker says something about Maria in w

2. John says something about Maria in w' (world of the reported speech act) 
In the embedded variant the addressee cannot be defined. That is why Portner (forthc.) dispenses with the addressee-oriented version of the expressive meaning for E-LD, and proposes the version introduced in (16) without explicitly mentioning the addressee.

As Frey (2004a) shows, E-LD formally and functionally corresponds in German to a construction called Hanging Topic $\left(\mathrm{HT}^{11}\right)$, as in (18):

a. Mary, I like her a lot.

E-LD

b. Mary, ich mag sie wirklich sehr.

Mary I like her really very-much.

This suggests that HT has the same expressive meaning as E-LD, cf. (19):

(19) Mary, I like her a lot. / Mary, ich mag sie wirklich sehr.

at-issue meaning: $\quad[\lambda \mathrm{w}$. speaker likes Mary in $w]$

expressive meaning: $\{[\lambda \mathrm{w}$. speaker's mental representation of Mary is active in $w]\}$

$\left[\left[\mathrm{NP}_{\mathrm{HT}}\right]\right]_{\mathrm{c}}^{\mathrm{C}}=\quad\{[\lambda \mathrm{w}$. speaker's mental representation of the referent of the NP is active in $w]$ \}

Frey (2004b) argues that the discourse function of HT in German is to mark the introduction of a new discourse topic referent, ${ }^{12}$ as in (20):

(20) (Hans ist ein richtiger Fan der Berliner U-Bahn. Deshalb reist er oft nach Berlin.)

(Hans is a real fan of the Berlin underground. That's why he rather often goes to Berlin.)

Die Berliner U-Bahn, sie nahm 1902 ihren Betrieb auf. Sie $_{\mathrm{i}}[\ldots]$

The Berlin underground FEMi $_{\text {she }}$ took 1902 her operating on. She $[$ [...]

The Berlin underground, it started operating in 1902. It [...]

[Frey $(2004 b,(57))$ ]

In (20), the discourse topic referent of the first two utterances is Hans, and then it changes to the Berlin underground; this change is explicitly signalled through HT. However, expressive meaning in (19) does not capture this signalling of a change of the discourse topic referent ${ }^{13}$.

11 Altmann (1981) and the following tradition distinguishes between two left dislocation constructions in German, Left dislocation (LD) and Hanging Topic (or 'free theme', HT), cf. (a) and (b):

(a) Den $\mathrm{Hans}_{\mathrm{i}}$, den $\mathrm{i}_{\mathrm{i}}$ mag jeder.

the $_{A K K}$ Hans D-PRON $A K K$ likes everyone

(b) Der / Den Hans, jeder mag ihn.

the $_{N O M}$, the AKK $_{\text {Hans everyone likes him }}$ [FKK (2004 a: 205)]

As shown in Frey (2004 a), LD is prosodically and syntactically integrated into its host sentence; it allows only weak d-pronouns (der, die, das) as clause-internal resumptive forms. The LD-NP resp. the resumptive form is the sentence topic of its host sentence. HT is prosodically and syntactically independent; it allows various resumptive forms, and, being independent, it does not play any syntactic role in its host sentence, but serves to mark the change of the discourse topic.

${ }^{12}$ Frey (2004) uses the term 'discourse topic'; however, his understanding of discourse topic as the "main theme of a Section of a text" (Frey (2004: 217)) corresponds to what I call the 'discourse topic referent' in this paper.

${ }^{13}$ Frey (2004b) argues that HT is not suitable with maintained discourse topic referents, cf. (a):

(a) (A propos Maria: Weißt Du, wen sie in Berlin getroffen hat?)

(As for Maria, do you know whom she met in Berlin?)

\#Maria, sie hat in Berlin Hans getroffen.

Maria she has in Berlin Hans met. (Maria, she met Hans in Berlin.)

[modified after Frey (2004b: 108)]

Thus, the expressive meaning "speaker's mental respresentation of X is active" is too weak for HT (and presumably also E-LD). Besides, one might argue that every mentioning of $\mathrm{X}$ irrespective of a particular construction used signals that the speaker's mental representation of X is active (see also criticism in Potts et al. (2004)). 
Thus it seems to be too weak for HT. Taking the discourse topic change function of HT into account, the expressive meaning of HT is revised in (21):

(21) Maria, ich mag sie wirklich sehr.

$$
\begin{aligned}
& {\left[\left[\mathrm{Maria}_{\mathrm{HT}}\right]\right]_{\mathrm{c}}^{\mathrm{C}}\{[\lambda \mathrm{w} \text {. speaker signals that he is starting to talk about Maria in } \mathrm{w}]\}} \\
& \left.\left[\mathrm{NP}_{\mathrm{HT}}\right]\right]_{\mathrm{c}}^{\mathrm{C}}=\quad\{[\lambda \mathrm{w} \text {. speaker signals that he is starting to talk about the referent of } \\
& \text { the NP in } \mathrm{w}]\}
\end{aligned}
$$

\subsection{Expressive meaning of German RD}

As I argue in Averintseva-Klisch (forthc. b), German RD and HT share one feature in that they both mark the referent of the NP as the discourse topic referent for the following discourse segment. This suggests that RD (as well as HT) introduces the expressive meaning "the speaker signals that he is starting to talk about X', where $\mathrm{X}$ is the referent of the RD-NP, cf. (22) (that is a part of the discourse in (10) above):

$$
\begin{aligned}
& \text { Sie war ein Original, die Madame Dutitre. } \\
& \text { She was an original the Madame Dutitre } \\
& \text { (She was somewhat special, that Madame D.) }
\end{aligned}
$$

at-issue meaning: $\quad[\lambda \mathrm{w}$. Madame Dutitre was somewhat special in $\mathrm{w}]$

expressive meaning: [[Madame Dutitre $\left.\left.{ }_{\mathrm{RD}}\right]\right]_{\mathrm{c}}^{\mathrm{C}}=\{[\lambda \mathrm{w}$. speaker signals that he is starting to talk about Madame Dutitre in w]\}

The at-issue-meaning of (22) does not differ from that of (23):
Madame Dutitre war ein Original.
Madame Dutitre was an original
(Madame D. was somewhat special.)
at-issue meaning: $\quad[\lambda \mathrm{w}$. Madame Dutitre was somewhat special in w]

(22), as well as (23), is true iff Madame Dutitre is somewhat special ${ }^{14}$ in w. The difference between (22) and the unmarked form in (23) is that in (22) Madame Dutitre is explicitly marked as the discourse topic referent for the following segment, whereas in (23) this stays implicit.

However, RD differs from HT in a crucial way: HT always signals a change of the discourse topic referent. For RD, there are two possibilities: one is that the speaker signals the introduction of a new discourse topic referent, as is the case with the discourse-initial RD. As shown in Averintseva-Klisch (forthc. a), RD may be used discourse-initially if the referent in question is presented as being discourse-old, cf. (23): ${ }^{15}$

(23) Es gibt sie noch, die guten Nachrichten aus der deutschen Universität. it gives them yet the good news from the german university

You can still find some - good news coming from German universities. (beginning of a lead)

Otherwise the speaker signals the maintenance of the old discourse topic referent. This is most often the case when the discourse topic referent is maintained in spite of the beginning

\footnotetext{
${ }^{14}$ In this case, a property which has to be defined in the context. I ignore the semantic contribution of the tense for the moment.

${ }^{15}$ I argue that in such cases RD implicitly embeds the beginning discourse into some larger, thematically contiguous setting that is familiar to the author and the recipient of the discourse. In (23) such 'meta-discourse' is a series of articles about the German university system and its future in the weekly German periodical Die ZEIT. The use of a RD is a most economic means of simultaneously introducing a referent, presenting it as being discourse-old and marking it as the discourse topic referent for the following discourse segment (see Averintseva-Klisch (forthc. a) for details).
} 
of a new segment, as in (22) resp. (10). Here the new discourse segment (corresponding to the new paragraph ${ }^{16}$ ) begins, but Madame Dutitre remains the discourse topic referent.

To get to the point: HT always signals the change of the discourse topic referent (cf. Frey (2004a\&b)), whereas RD allows both change and maintenance. Thus, the expressive meaning of (22) should be changed in the following way: "the speaker signals that he is (further on) going to talk about Madame Dutitre":

(24) Sie war ein Original, die Madame Dutitre.

expressive meaning: [[Madame Dutitre $\left.\left.{ }_{\mathrm{RD}}\right]\right]_{\mathrm{c}}^{\mathrm{C}}=\{[\lambda \mathrm{w}$. speaker signals that he is (further on) going to talk about Madame Dutitre in w]

The expressive meaning of RD is thus restated in (25):

(25) $\left[\left[\mathrm{NP}_{\mathrm{RD}}\right]\right]_{\mathrm{c}}^{\mathrm{C}}=\{[\lambda \mathrm{W}$. speaker signals that he is (further on) going to talk about the referent of the NP in $w]\}$

Now, let us have a look at embedded RD, cf. (26):

(26) Hans sagte, dass sie richtig nett ist, die Grete.

Hans said that she really nice is the Grete.

at-issue meaning: $\quad[\lambda \mathrm{w}$. Hans said that Grete is nice in $w]$

expressive meaning: 1 . $\{[\lambda \mathrm{w}$. speaker of the main clause signals that he is (further on) going to talk about Grete in w]

2. * $\{[\lambda \mathrm{w}$. Hans signals that he is (further on) going to talk about Grete in w']\}

In contrast to embedded topics in English (E-LD), there is no embedded reading for RD. ${ }^{17}$ This means, that a slight modification of the expressive meaning of RD is needed. (25) is thus restated as (27):

(27) $\left[\left[\mathrm{NP}_{\mathrm{RD}}\right]\right]_{\mathrm{c}}^{\mathrm{C}}=\{[\lambda \mathrm{W}$. speaker (of the host sentence) signals that he is (further on) going to talk about the referent of the NP in w] $\}^{18}$

In other words, RD adds to the semantics of its host sentence a separate performative explicitly signalling that the speaker is going to talk about the referent of the RD-NP, while it is left open whether he was already talking about this referent or just changed to a new topic.

In the next section I will show how certain semantic peculiarities of RD may be accounted for with the separate performative analysis proposed in (27).

\footnotetext{
${ }^{16}$ The preceding segment gives an example of Madame Dutitre's original sayings; the beginning segment is giving some general information about Madame Dutitre, for which the preceding segment may serve as an illustration.

${ }^{17}$ This means that for RD, contrary to E-LD, it would be possible to have an explicit reference to the addressee. However, this does not seem necessary: intuitively, RD is a strategy that serves to mark the information status of a certain NP that is used by the speaker, and the reference to the speaker making a signal with the RD seems to me to capture this intuition in the best way.

${ }^{18}$ In my paper I consider only NP-RD. Altmann (1981) describes also briefly PP- and CP-'right dislocation' (which he distinguishes from extraposition). It requires further analysis to find out whether these constructions are really RDs or ATs. That is why I state (24) explicitly for NP-RD. However, when needed, (27) can be generalized to $\left[\left[\mathrm{XP}_{\mathrm{RD}}\right]\right]_{\mathrm{c}}^{\mathrm{C}}=\{[\lambda \mathrm{W}$. speaker signals that he is (further on) going to speak about the referent of $\mathrm{X}$ in $\mathrm{w}]\}$.
} 


\section{Consequences of the separate performative account of RD}

The semantic analysis of RD proposed in the previous section accounts for certain restrictions concerning the semantic status of the NP in the RD. Thus, quantificational NPs in general seem not to be possible with RD. Besides, the separate performative account of RD explains the discourse function of the RD in a most straightforward way.

\subsection{Explaining certain semantic constraints on the RD-NP}

It has been noticed that quantified NPs are in general bad with RD, as in $(28)^{19}$ (see also Averintseva-Klisch (forthc. b)):

$\begin{array}{llllll}\text { Peter liebt sie, } & * \text { jede Frau / *keine } & \text { Brünetten } / * \text { zwei } & \text { Frauen. } \\ \text { Peter loves her/them *every } & \text { woman / *no } & \text { brunettes } / * \text { two } & \text { women }^{20} .\end{array}$

This can be accounted for if one assumes that the contribution RD makes to the semantics of its host sentence is an expressive meaning. To show this I first refer to Portner's (forthc.) analysis of vocatives.

Portner (forthc.) notices that quantifiers are in general unable to function as vocatives, cf. (29):

(29) Anna / *Some woman, please, hurry up!

The semantics of vocatives is assumed to be (30) (cf. Portner (forthc.: 9)):

(30) at-issue meaning: $\quad[\lambda x \lambda w$. speaker urges $x$ to hurry up in $w]$

expressive meaning: $\{[\lambda \mathrm{x} \lambda \mathrm{w}$. speaker requests the attention of $\mathrm{x}$ in $\mathrm{w}]\}$

In the expressive meaning formula in (30), $\mathrm{x}$ can be only of type e. Thus, to be able to function as an argument at the level of the expressive meaning, the quantifier some has to raise from the type $\langle e,\langle e, t\rangle\rangle^{21}$ to the type e. In raising to type e, the quantifier changes to the at-issue meaning level, leaving a trace behind at the expressive meaning level. This trace has to be semantically bound by the quantifier (see Heim (1982)). This is, however, not possible. Portner (forthc.) argues that it is impossible to bind "across dimensions of meaning": a quantifier which contributes to at-issue meaning cannot bind a variable which contributes to expressive meaning (see Portner (forthc.) for details).

In a similar way, the impossibility of semantic binding across dimensions accounts for the illformedness of quantificational NPs in RD constructions in (28). The quantifier jede / keine / zwei has to raise to type e to be able to function as an argument of the expressive meaning $\{[\lambda x \lambda w$. speaker (of the host sentence) signals that he is (further on) going to talk about $x$ in $w]\}$; thus it moves to at-issue meaning and cannot bind its trace at the expressive level any more.

\subsection{The semantics of $\mathrm{RD}$ and discourse topic referent}

Besides explaining the impossibility of certain kinds of NPs in RD, the separate performative account provides a straightforward explanation for the contrast in (31):

\footnotetext{
${ }^{19}$ Grewendorf (2002) notices the same for LD. I do not attempt any explanation of this fact here.

${ }^{20}$ Note that these sentences are well-formed without RD:

(b) Peter liebt jede Frau / keine Brünetten / zwei Frauen. Peter loves every woman / no brunettes / two women

${ }^{21}$ This being the semantic type of this kind of quantifier, cf. Heim and Kratzer (1997).
} 
a. "Ein Taifun!" rief Lukas dem Kapitän zu. "Da ist er!"" Ja, da war "A typhoon!" called Lukas the captain to. "Here is he!" Yes, here was er, der Taifun. Ein hellblauer Blitz fuhr zischend vom he the typhoon $_{\text {MASK. }}$ A light-blue lightning went whizzing from-the Himmel nieder [...] sky downwards [...]

[M. Ende, Jim Knopf und die Wilde 13: 190]

b. "Ein Taifun!" rief Lukas dem Kapitän zu. "Da ist er!" \#Er lief zum "A typhoon!" called Lukas the captain to. "Here is he!" He ran to-the Steuer, der Lukas. Ein hellblauer Blitz fuhr zischend vom steering-wheel the Lukas. A light-blue lightning went whizzing from-the Himmel nieder [...] sky downwards $[\ldots]^{22}$

Here, RD is only possible with the NP der Taifun; no other NP, as der Lukas as in (31b) might be right-dislocated, even if the corresponding referent is discourse-old and also otherwise complies with the requirements on the RD-NP. This changes, however, as soon as the following discourse segment is adapted so that its discourse topic referent corresponds to the referent of the RD-NP: RD is perfectly well-formed, cf. (32):

$$
\begin{aligned}
& \text { "Ein Taifun!" rief Lukas dem Kapitän zu. "Da ist er!" Er lief zum } \\
& \text { "A typhoon!" called Lukas the captain to. "Here is he!" He ran to-the } \\
& \text { Steuer, der Lukas. Dort angekommen, riss er sein Hemd runter und band } \\
& \text { steering-wheel the Lukas. There arrived tore he his shirt down and bound } \\
& \text { damit das Steuerrad fest. } \\
& \text { with-it the steering-wheel firmly. }
\end{aligned}
$$

That means that RD is suitable with a NP referring to the discourse topic referent; otherwise only AT is possible. This follows directly from the expressive meaning that RD contributes to the semantics of its host sentence: with a RD the speaker signals that he is going to talk about the referent of the RD-NP. And it is pragmatically unsound first to mark a referent as being what one is going to talk about, and then to change the subject.

\section{Summary and conclusions}

In my paper, I have shown that what is traditionally subsumed under the label of German right dislocation are in fact two different constructions: right dislocation proper and afterthought. RD and AT differ in their formal and functional properties. AT is an 'orphan' that gets integrated into its host sentence only at the discourse level. Its discourse function is to resolve a potentially unclear (pro)nominal reference. RD is prosodically and syntactically a part of its host sentence. Its function is to mark the discourse topic referent for the following discourse segment.

The main goal of this paper was to show that RD adds a separate performative (an 'expressive meaning') to the semantics of the sentence. This performative is "the speaker (of the host sentence) signals that he is (further on) going to talk about $X$ ", with $\mathrm{X}$ being the referent of the RD-NP. This account of the RD explains certain constraints on the semantic status of the RD-NP: only NPs of the type e are possible here. This corresponds to ontological constraints on the discourse topic referent: only definite individual nominal referents are possible.

Furthermore, I argue that the discourse function of RD is to mark the discourse topic referent, as follows directly from the semantics of RD. I believe that for an approach to the otherwise highly elusive pragmatic category of the discourse topic it is a prerequisite to have a look at

\footnotetext{
${ }^{22}$ (33b) is thouroughly acceptable as AT, with the corresponding prosody, but not as RD.
} 
explicit linguistic means of referring to it. In this sense RD in its function of marking the discourse topic referent is an explicit means revealing something of how the discourse model is built up.

\section{References}

Altmann, H.: 1981, Formen der 'Herausstellung' im Deutschen: Rechtsversetzung, Linksversetzung, Freies Thema und verwandte Konstruktionen. Tübingen: Niemeyer.

Asher, N. and Lascarides, A.: 2003, Logics of Conversation. Cambridge: CUP.

Asher, N.: 2004 a, Discourse topic, Theoretical Linguistics 30, 163-201.

Asher, N.: 2004 b, Troubles with topics: comments on Kehler, Oberlander, Stede and Zeevat, Theoretical Linguistics 30, 255-262.

Auer, P.: 1991, Vom Ende deutscher Sätze, Zeitschrift für Germanistische Linguistik 19, 139157.

Averintseva-Klisch, M.: forthc. a, Anaphoric properties of the German right dislocation, in M. Schwarz-Friesel, M. Consten and M. Knees (eds.), Anaphors in Text.

Averintseva-Klisch, M.: forthc. b, German Right Dislocation and Afterthought in Discourse, in C. Sassen, A. Benz and P. Kühnlein (eds.), Constraints in Discourse.

Brown, G. and Yule, G.: 2004, Discourse analysis. Cambridge: CUP [reprinted from original of 1983].

Fretheim, T.: 1995, Why Norwegian Right-Dislocated Phrases are not Afterthoughts, Nordic Journal of Linguistics 18, 31-54.

Frey, W.: 2004a, Notes on the syntax and pragmatics of the German Left Dislocation, in H. Lohnstein and S. Trissler (eds.), The Syntax and Semantics of the Left Periphery, Mouton de Gruyter, pp. 203-233.

Frey, W.: 2004b, Pragmatic properties of certain German and English left peripheral constructions. Linguistics 43/1, 89-129.

Goutsos D.: 1997, Modeling Discourse Topic: Sequential Relations and Strategies in Expository Text. Norwood: Ablex (= Advances in Discourse Processes LIX).

Grewendorf, G.: 2002, Minimalistische Syntax. Tübingen / Basel: A. Francke (= UTB 2313).

Haegeman, L.: 1991, Parenthetical adverbials: The radical orphan approach, in S. Chiba et al. (eds), Aspects of modern English linguistics: Papers presented to Masatomo Ukaji on his 60th birthday. Kaitakusha, pp. 232-254.

Heim, I.: 1982, The Semantics of Definite and Indefinite Noun Phrases. Ph.D. Thesis, MIT.

Heim, I. and Kratzer, A.: 1997, Semantics in Generative Grammar. Oxford: Blackwell.

Kehler, A.: 2004, Discourse topics, sentence topics, and coherence, Theoretical Linguistics 30, 227-240. 
Oberlander, J.: 2004, On the reduction of discourse topic, Theoretical Linguistics 30, 213225.

Portner, P.: 2004, Vocatives, Topics and Imperatives, handout for IMS Workshop on Information Structure, Bad Teinach, URL: http://www.georgetown.edu/faculty/ portnerp/

Stuttgart_handout.pdf.

Portner, P.: forthc, Instructions for Interpretation as Separate Performatives, in K. Schwabe and S. Winkler (eds.), On Information Structure, Meaning and Form. Amsterdam: Benjamins.

Potts, Ch.:2003, The performative nature of expressive content, handout, URL http://wwwunix.oit.umass.edu/ potts/potts-expressives-uconn-rochester.pdf.

Potts, Ch.: 2004, Conventional implicatures, a distinguished class of meanings, in G. Ramchand and Ch. Reiss (eds.), The Oxford Handbook of Linguistic Interfaces. OUP, pp. 187-198.

Potts, Ch. , Schwarz, F. and Kawahara, Sh.: 2004, Comments on Paul Portner's 'Instructions for Interpretation as Separate Performatives', handout for Harvard-MIT-UConn Indexicality Workshop Nov. 20, 2004, URL http://www-unix.oit.umass.edu/ potts/talks/pottsschwarz-kawahara-cmts-on-portner.pdf.

Potts, Ch.: 2005, The Logic of Conventional Implicature. Oxford: OUP.

Prince, E.: 1992, The ZPG Letter: Subjects, Definiteness, and Information-Status, in W. Mann and S. Thompson (eds.), Discourse Description. Diverse linguistic analyses of a fundraising text. Amsterdam: Benjamins, pp. 295-325.

Selting, M.: 1994, Konstruktionen am Satzrand als interaktive Ressource in natürlichen Gesprächen, in B. Haftka (ed.), Was determiniert Wortstellungsvariation?, Westdeutscher Verlag, pp. 299-318.

Shaer, B. and Frey, W.: 2004, 'Integrated' and 'Non-integrated' Left-Peripheral Elements in German and English, in B. Shaer, W. Frey and C. Maienborn (eds.), Proceedings of the Dislocated Elements Workshop, ZAS Berlin, November 2003. ZAS Papers in Linguistics 35, 465-502.

Stede, M.: 2004, Does discourse processing need discourse topics?, Theoretical Linguistics 30, 241-253.

Uhmann, S.: 1997, Grammatische Regeln und konversationelle Strategien. Fallstudien aus Syntax und Phonologie. Tübingen: Niemeyer.

Ward, G. and Birner, B.: 1996, On the Discourse Function of Rightward Movement in English, in A. Goldberg (ed.), Conceptual Structure, Discourse and Language. Stanford Center for the Study of Language and Information Publications, pp. 463-479.

Zeevat, H.: 2004, Asher on discourse topic, Theoretical Linguistics 30, 203-211. 